\title{
Salisilik asit uygulamasının aspir (Carthamus tinctorius L.) çeşitlerinin verim ve bazı kalite özelliklerine etkisinin araştırılması*
}

\author{
Emrullah CULPAN1, Burhan ARSLAN1
}

1Namık Kemal Üniversitesi, Ziraat Fakültesi, Tarla Bitkileri Bölümü, 59030, TEKIRDAĞ

*Bu araștırma Emrullah CULPAN’ın yüksek lisans tezinden üretilmiș, 12. Tarla Bitkileri Kongresinde poster sunu olarak sunulmuş ve kongre kitapçığında özet bildiri olarak basılmıștır.

Alınış tarihi: 22 Şubat 2018, Kabul tarihi: 21 Mayıs 2018

Sorumlu yazar: Emrullah CULPAN, e-posta:eculpan@nku.edu.tr

\section{Öz}

$\mathrm{Bu}$ araştırmada, salisilik asit uygulamasının aspir çeşitlerinin verim ve bazı kalite özelliklerine etkilerinin belirlenmesi amaçlanmıștır. Çalıșma, Namık Kemal Üniversitesi Ziraat Fakültesi Tarla Bitkileri deneme alanında 2014 ve 2015 yllarında olmak üzere iki yll süreyle yürütülmüștür. Deneme Tesadüf Bloklarında Bölünmüş Parseller Deneme Desenine göre 3 tekrarlamalı olarak kurulmuştur. Araştırmada metaryal olarak iki aspir çeşidi (Dinçer ve Balcı) ve salisilik asidin 4 dozu (0, 0.1, 0.5 ve $1 \mathrm{mM}$ ) kullanılmıștır. Sonuçlar incelendiğinde SA uygulamasının aspir tohumlarında protein oranını artırıcı yönde teşvik ettiği görülürken, tohum verimi ve yağ oranı ortalamaları arasındaki fark önemsiz bulunmuştur. Her iki yılda da en yüksek tohum verimi Dinçer çeşidinden elde edilmiștir (sırasıyla 120.49 ve $122.89 \mathrm{~kg} / \mathrm{da}$ ). Çeşit x doz interaksiyonlarının protein oranına etkisi önemli bulunmuș ve her iki yılda da en yüksek protein oranı 0.1 mM SA uygulamasıyla Balcı çeșidinden elde edilmiștir (sırasıyla \%17.15 ve \%16.98). Sonuç olarak, protein oranı küspenin hayvan yemi olarak değerlendirilmesinde önem arz ettiğine göre, salisilik asit uygulaması pratik bir yöntem olabilir.

Anahtar Kelimeler: Aspir, salisilik asit, yağ oranı

Effects of applications salicylic acid on seed yield and some quality traits of safflower cultivars (Carthamus tinctorius L.)

\section{Abstract}

The aim of this study was to determine effects of salicylic acid (SA) on yield and some quality components of safflower (Carthamus tinctorius L.). This research was conducted at Applying Research Field, Faculty of Agriculture, Namık Kemal University, Tekirdağ in 2014 and 2015. The experiment was laid out as a split plot design based on Randomized Complete Block Design with three replications, in which cultivars constituted the main plot with two cultivars (Dinçer and Balcl), and salicylic acid constituted the sub-plot with four doses $(0,0.1,0.5$ and $1 \mathrm{mM})$. According to the results, variation in doses of salicylic acid had a significant effect on protein content, but the differences between seed yield and oil content means was found not significant. Results show that Dinçer cultivar has showed the highest seed yield both 2014 and 2015 (120.49 and $122.89 \mathrm{~kg} / \mathrm{da}$ respectively). In terms of protein content, the application of SA was found significant statistically and the highest protein content was obtained from Balcl cultivar with application of $0.1 \mathrm{mM} \mathrm{SA}$ in two years (\%17.15 and \%16.98 respectively). As a result, application of SA may be a practical method, because the protein content is important for the evaluation of the residue as animal feed.

Key words: Safflower, salicylic acid, oil content

\section{Giriş}

Aspir (Carthamus tinctorius L., Asteraceae), 3000 yll önce Ortadoğu'da kültüre alınmaya başlamış önemli bir yă̆ bitkisidir. Tohumlarında \% 90'ı doymamıș yağ asitlerinden (oleik ve linoleik asit) oluşan \% 2545 arasında yağ, \% 32-34 karbonhidrat, \% 14-15 protein, \% 5-8 nem ve \% 2-7 kül ihtiva etmektedir (Weiss, 2000). Ayrıca yağı yemeklik olarak kaliteli ve E vitamini içeren (Arslan ve ark., 2003), küspesi ve karışımı hayvan yemi olarak değerlendirilen, kışlık 
ve yazlık formları bulunan değerli bir yağ bitkisidir (İşler, 2010; Arslan ve ark., 2012).

2016 yılı verilerine göre dünya genelinde 1.1 milyon ha alanda aspir tarımı yapılmış, 950 bin ton tohum üretilmiş ve Rusya, Kazakistan, Meksika, ABD, Türkiye ve Hindistan bu üretimin yaklaşı \% $\% 3$ 'ünü karşılamıştır (Anonymous, 2016). Türkiye'de son yıllarda aspir üretim alanları düzenli bir artış göstermeyip, 2017 yllında 27.376 ha alandan 50 bin ton aspir üretilmiştir. Dekar başına verim ise 2017 yllında 183 kg olmuştur (Anonim, 2017).

Aspir, ekolojik istekleri bakımından seçici olmaması ve diğer yağ bitkilerine nazaran düşük sıcaklıklara daha dayanıklı olması, bitkiye farklı iklimlerde üretim alanı sağlamaktadır (Bayraktar, 1991). Öte yandan kurağa dayanıklılığı ve sulanmadan yetiştirilmesi, özellikle nadas alanlarının değerlendirilmesine firsat veren (Esendal, 1981), ülkemiz yağ açı̆̆ını kapatma potansiyeline sahip yă bitkilerinden biri olabilecektir. Ayrıca çiçeklerinin taç yaprakları gıda ve tekstil sanayinde renk verici olarak da kullanılmaktadır. Yalancı safran olarak bilinen aspir çiçeğinden carthamin $\left(\mathrm{C}_{43} \mathrm{H}_{42} \mathrm{O}_{22}\right)$, (\%0.3-0.6) adı verilen boyar madde elde edilir. Carthamin ayrıca tıbbi olarak birçok yerde kullanılır (Dajeu ve Mündel, 1996). Kültür bitkilerinde birim alandan elde edilen verim, bitkinin genotipine, çevre faktörlerine ve agronomik uygulamalara bağlıdır. Agronomik uygulamalardan olan bitki büyüme düzenleyicilerinin (BBD) kullanılması özellikle verim ve kalite üzerine önemli etkilere sahiptir. Son yıllarda bazı büyüme düzenleyicilerinin bitki ürün kalitesinin geliştirilmesi ve verime etkileri konusunda birçok araştırma yapılmış olup bu konuyla ilgili çalışmalar devam etmektedir.

Günümüzde çimlenmeden hasada ve hasat sonrası muhafazaya kadar bitkinin büyüme oranını ve gelişmesini etkilemek amacıyla yaygın olarak kullanılan BBD'lerinin verim üzerine olan etkileri genelde dolaylı yoldan olmaktadır (Budak ve ark., 1994). Bitkilere bu maddelerin dişsal uygulanmasında amaca uygun kimyasalın seçimi, uygun konsantrasyonun ve uygulama zamanının belirlenmesi istenen etki için oldukça önemlidir (Palavan-Ünsal, 1993; Buban, 2000). Tarihi seyri en iyi bilinen bitki büyüme düzenleyicilerinin başında salisilik asit $\left(\mathrm{C}_{7} \mathrm{H}_{6} \mathrm{O}_{3}\right)(\mathrm{SA})$ gelmektedir. Latince Salix (sögüt) sözcügünden gelen salisilik asidin adı ilk olarak 1838 yılında Raffaele Piria isimli araştırıcı tarafından kullanılmıştır. Sentetik salisilik asidin ilk ticari üretimi 1874 yılında Almanya'da yapılmıştır. Salisilik asidin bitki biyolojisinde kullanımı ise daha çok son 30-40 yıl içerisinde yapılan araştırmalar sonucunda başlamıştır. SA sentezlendiği veya dışarıdan uygulandığı yerden floem yoluyla bitki bünyesinde farklı organlara kolayca taşınmaktadır (Kleier, 1988). Shakirova ve ark. (2003) salisilik asidin genç ekmeklik buğday (Triticum aestivum L.) fidelerini büyümeye teşvik ettiğini ve daha büyük başak boyu, daha yüksek 1000 tane ağırlığı ve tane verimi elde ettiğini bildirmişlerdir. Ebrahimzadeh ve ark. (2009), aspire uygulanan $0.1 \mathrm{mM}$ salisilik asit dozunun kontrolle karşılaştırıldığında tabladaki çiçek sayısını \%108, tohum verimini $\% 83$ ve hasat indeksini \%21 artırdığını bildirmiştir. Mona ve ark. (2012) artan salisilik asit dozlarının ayçiçeği tohumlarında protein oranını önemli bir şekilde artırdığını bildirmişlerdir. Arpada salisilik asit uygulamalarının tohum çıkışı, başaklanma ve bin tane ağırlığını artırdığı bildirilmiştir (Khaliliaqdam ve ark., 2013). Salisilik asidin aspirde çimlenme ve tane verimi üzerine yapılan çalışmada en yüksek tane veriminin $50 \mathrm{mg} / \mathrm{l}$ salisilik asit dozundan elde edildiği bildirilmiştir (Moghadam ve Muhammedi, 2014). Bu çalışma Tekirdağ ekolojik koşullarında farklı salisilik asit dozlarının Dinçer ve Balcı aspir çeşitlerinin verim, verim unsurları, yağ oranı ve protein oranı üzerine olan etkisini belirlemek amacıyla yürütülmüştür.

\section{Materyal ve Yöntem}

\section{Araştırma yerinin iklim ve toprak özellikleri}

Araştırma, Namık Kemal Üniversitesi Ziraat Fakültesi Tarla Bitkileri Bölümü araştırma deneme arazisinde yazlık ekim yapılarak tek lokasyonda (Tekirdağ), 2014 ve 2015 yıllarında yürütülmüştür. Araştırma yerinin toprakları killi bir bünyeye sahip olup, $\mathrm{pH}$ 'sı hafif alkali (7.38) ve organik madde bakımından düşük (\%1.16) seviyededir. Kireç içeriği düşük olan toprakların (\%2.37), fosfor seviyesi de düşük (3.69 $\mathrm{kg} / \mathrm{da}$ ) olup, tuzluluk problemi yoktur. Araştırmanın yürütüldüğü 2014 ve 2015 yıllarında ortalama sıcaklık değerleri uzun yıllar ortalamasından yaklaşık $1^{\circ} \mathrm{C}$ daha yüksek değer göstermiştir. Toplam yağış miktarı ise ilk yll $414.7 \mathrm{~mm}$ ile uzun yıllar ortalamaları toplamından yaklaşık 2 kat değere sahip iken, ortalama oransal nem değerleri ise uzun yıllar ortalamasına yakın değerlerde seyretmiştir (Çizelge 1). 
Çizelge 1. Tekirdağ (Merkez)'ın aspir yetiştirme aylarına ait 2014/2015 yılı ve uzun yıllar iklim verileri*

\begin{tabular}{|c|c|c|c|c|c|c|c|c|c|}
\hline \multirow[b]{2}{*}{ Aylar } & \multicolumn{3}{|c|}{ Ortalama Sicaklık ( $\left.{ }^{\circ} \mathrm{C}\right)$} & \multicolumn{3}{|c|}{ Toplam Yağıș (mm) } & \multicolumn{3}{|c|}{ Oransal Nem (\%) } \\
\hline & 2014 & 2015 & $\begin{array}{l}\text { Uzun } \\
\text { Yillar }\end{array}$ & 2014 & 2015 & $\begin{array}{l}\text { Uzun } \\
\text { Yillar }\end{array}$ & 2014 & 2015 & Uzun Yıllar \\
\hline Mart & 9.9 & 8.5 & 7.3 & 73.6 & 29.7 & 55.2 & 81.6 & 81.9 & 81.1 \\
\hline Nisan & 13.4 & 11.4 & 11.9 & 46.8 & 65.2 & 40.9 & 83.3 & 74.3 & 78.8 \\
\hline Mayıs & 17.5 & 18.6 & 16.8 & 72.1 & 32.2 & 38.7 & 80.3 & 76.3 & 77.3 \\
\hline Haziran & 21.8 & 21.3 & 21.3 & 69.6 & 62.8 & 37.0 & 76.2 & 73.3 & 73.7 \\
\hline Temmuz & 24.8 & 24.9 & 23.8 & 72.1 & 0.5 & 23.1 & 73.0 & 70.6 & 70.4 \\
\hline Ağustos & 25.3 & 26.1 & 23.7 & 80.5 & 0.0 & 14.5 & 74.5 & 68.9 & 71.4 \\
\hline Ort./Top. & 18.8 & 18.5 & 17.5 & 414.7 & 190.4 & 209.4 & 78.2 & 74.2 & 75.5 \\
\hline
\end{tabular}

*Tekirdağ Meteoroloji İstasyonu Verileri

\section{Materyal ve metot}

Araştırmada, Eskişehir Geçit Kuşağı Tarımsal Araştırma Enstitüsü tarafından geliştirilmiş olan Dinçer ve Balcı aspir çeşitleri kullanılmıştır. Salisilik asit, her parsele 2 litre SA çözeltisi düșecek şekilde 0, 0.1, 0.5 ve 1 mM'lık konsantrasyonları hazırlanarak çiçeklenme öncesi püskürtme yoluyla bitkiye verilmiştir. Deneme, 'Tesadüf Bloklarında Bölünmüş Parseller Deneme Desenine' göre 3 tekrarlamalı olarak yürütülmüştür. Her çeşit $5 \mathrm{~m}$ uzunluğundaki parsellere sıra arası $20 \mathrm{~cm}$, ekim derinliği $3-4 \mathrm{~cm}$ ve 6 $\mathrm{kg} /$ da tohumluk kullanılarak 6 sıra halinde elle ekilmiștir. Toprak analiz sonucuna göre dekara $12 \mathrm{~kg}$ saf azot ve $6 \mathrm{~kg}$ saf fosfor verilmiştir. Azotun yarısı ekimle beraber diğer yarısı bitkiler sapa kalktığında, fosforun ise tamamı ekimle birlikte verilmiştir. Araştırmada, tabladaki tohum sayısı (adet), tabla çapı (cm), 1000 tane ağırlığı (g), kabuk oranı (\%), tohum verimi $(\mathrm{kg} / \mathrm{da})$, yağ oranı (\%) ve ham protein oranı (\%) gibi karakterler ölçülmüştür.

\section{Verilerin değerlendirilmesi}

Araştırma sonucunda elde edilen veriler tesadüf blokları deneme desenine göre varyans analizi yapılmıştır. Uygulamalar arasındaki farklılıkların önem düzeyini belirlemek için LSD testi kullanılmıştır. Verilerin analizinde TARIST (Açıkgöz ve ark., 1993) ve MSTAT-C (MSTAT, 1989) istatistiki analiz paket programlarından faydalanılmıştır.

\section{Bulgular ve Tartışma}

\section{Tabladaki tohum sayısı (adet)}

Araştırma sonuçlarına göre, her iki yılda da tabladaki tohum sayısı bakımından çeșitler arasındaki fark önemli bulunmuştur $(\mathrm{P}<0.05)$. En yüksek tabladaki tohum sayısı 2015 yılında Balcı çeşidinden elde edilmiştir (31.525 adet). SA uygulamasının etkisi ise istatistiki açıdan önemsiz bulunmuştur $(\mathrm{P}>0.05)$. Fazian ve Bano (2011), yaptıkları çalışmada aspir bitkisine çiçeklenme döneminde uygulanan salisilik asidin tabladaki tohum sayısına etkisinin olmadığını bildirmişlerdir. Aspirde tabla sayısı kadar, tablada bulunan tohum sayısı da önemli bir verim kriteridir. Tablada tohum sayısı tabla iriliği ile doğrudan ilişkili (Uysal ve ark., 2006) olup, genetik ve çevresel faktörlerden oldukça etkilenebilmektedir.

\section{Tabla çapı (cm)}

Tabla çapı bakımından çeşitler arasındaki fark 2015 yılında önemli bulunmuş olup $(\mathrm{P}<0.05)$, en yüksek tabla çapı Dinçer çeşidinden elde edilmiştir (2.466 $\mathrm{cm})$. SA uygulamasının etkisi ise her iki yılda da istatistiki açıdan önemsiz bulunmuştur ( $\mathrm{P}>0.05)$. Aspirde ana sap tablası ile başlayarak üstten alta ve dıștan içe doğru devam eden düzenli bir interval mevcut olup, ilk çiçek açan tabladan son çiçek açan tablaya doğru tabla çapı değerleri azalmaktadır (Baydar ve Yüce, 1996). Aynı zamanda tabla çapı ile tohum verimi, tabla başına tohum sayısı, bin tohum ağırlı̆̆ı ve yağ içeriği arasında pozitif bir korelasyon mevcuttur (Çamaş ve ark., 2005). Araştırmamızda SA dozlarının tabla çapı üzerine olumlu etkide bulunmadığı, tabla çapı farklarının çeşit özelliklerinden kaynaklandığı sonucuna varılmıştır.

\section{Bin tane ağırlığı (adet)}

1000 tane ağırlığı bakımından her iki yılda da çeşitler arasındaki fark önemli bulunmuştur $(\mathrm{P}<0.05)$. En yüksek 1000 tane ağırlığı 2015 yılında Dinçer çeşidinden elde edilmiştir (53.024 g). 2014 yılında çeşit $\mathrm{x}$ doz interaksiyonu önemli bulunmuştur $(\mathrm{P}<0.05)$. Çeşit x doz interaksiyonunda en yüksek 1000 tane ağırlığı ise SA uygulanmayan kontrol parselinden elde edilmiştir. Bin tane ağırlığının yüksek olması tohumların iri, dolgun olduğunun bir göstergesidir (Öztürk, 1994). Tohum dolgunluğu özellikle çiçeklenme devresindeki iklim şartları ile direkt ilgilidir. Çiçeklenme döneminden sonra meydana gelebilecek yüksek sıcaklık ve kuraklık stresi, dane ağırlığının düşmesine, cılız ve kavruk danelere sebep olmaktadır (Modhej ve ark., 2008). Araştırmamızda SA dozlarının bin tane ağırlığına olumlu etkide bulunmadığı gözlemlenmiştir. 
Çizelge 2. Salisilik asit uygulamasının aspirin verim ve kalite özelliklerine etkisi (2014)

\begin{tabular}{|c|c|c|c|c|c|c|}
\hline \multirow{2}{*}{ Karakterler } & \multirow{2}{*}{ Çeşitler } & \multicolumn{4}{|c|}{ Dozlar } & \multirow{2}{*}{ Ortalamalar } \\
\hline & & $0 \mathrm{mM}$ & $0.1 \mathrm{mM}$ & $0.5 \mathrm{mM}$ & $1 \mathrm{mM}$ & \\
\hline \multirow{4}{*}{$\begin{array}{l}\text { Tabladaki Tohum } \\
\text { Sayısı (adet) }\end{array}$} & Dinçer & $23.167 \mathrm{bc}$ & $20.433 c$ & $26.800 \mathrm{ab}$ & $23.467 \mathrm{bc}$ & $23.467 \mathrm{~b}$ \\
\hline & Balcl & $29.800 \mathrm{a}$ & $29.733 a$ & 28.367 a & $27.467 \mathrm{a}$ & $23.842 \mathrm{a}$ \\
\hline & Ortalamalar & 26.483 & 25.083 & 27.583 & 25.467 & \\
\hline & $\mathrm{LSD}_{0,05}$ & Çeșit: 3,704 & Çeșit x Doz: 3,689 & & & \\
\hline \multirow{3}{*}{ Tabla Çapı (cm) } & Dinçer & 2.260 & 2.193 & 2.327 & 2.297 & 2.269 \\
\hline & Balcl & 2.277 & 2.337 & 2.253 & 2.307 & 2.293 \\
\hline & $\begin{array}{l}\text { Ortalamalar } \\
\text { LSD }_{0,05} \text { : }\end{array}$ & 2.268 & 2.265 & 2.290 & 2.302 & \\
\hline \multirow{4}{*}{$\begin{array}{l}1000 \text { tane ağırlı̆̆ } \\
\text { (g) }\end{array}$} & Dinçer & $47.225 \mathrm{a}$ & $43.400 \mathrm{bc}$ & $42.917 \mathrm{bc}$ & $42.108 \mathrm{bc}$ & $43.912 \mathrm{a}$ \\
\hline & Balcl & $42.167 \mathrm{bc}$ & $40.908 \mathrm{c}$ & $44.517 \mathrm{ab}$ & $43.092 \mathrm{bc}$ & $42.671 \mathrm{~b}$ \\
\hline & Ortalamalar & 44.696 & 42.154 & 43.717 & 42.600 & \\
\hline & $\mathrm{LSD}_{0,05}$ & Çeşit: 0,916 & Çeşit x Doz: 3,183 & & & \\
\hline \multirow{4}{*}{ Kabuk Oranı (\%) } & Dinçer & 48.320 & 47.587 & 47.947 & 48.517 & $44.093 \mathrm{a}$ \\
\hline & Balcl & 40.627 & 39.180 & 38.593 & 40.393 & $39.698 \mathrm{~b}$ \\
\hline & Ortalamalar & 44.473 & 43.383 & 43.270 & 44.455 & \\
\hline & $\mathrm{LSD}_{0,05:}$ & Çeșit: 1,122 & & & & \\
\hline \multirow{4}{*}{$\begin{array}{l}\text { Tohum Verimi } \\
\text { (kg/da) }\end{array}$} & Dinçer & $145.36 \mathrm{a}$ & $127.84 \mathrm{ab}$ & $120.26 \mathrm{bc}$ & $88.52 \mathrm{~d}$ & 120.49 \\
\hline & Balcl & $117.44 \mathrm{bc}$ & $103.81 \mathrm{~cd}$ & $121.98 \mathrm{bc}$ & $118.16 \mathrm{bc}$ & 115.35 \\
\hline & Ortalamalar & $131.40 \mathrm{a}$ & $115.82 \mathrm{bc}$ & $121.12 \mathrm{ab}$ & $103.34 \mathrm{c}$ & \\
\hline & $\mathrm{LSD}_{0,05:}$ & Doz: 12,609 & Çeșit x Doz: 18,696 & & & \\
\hline \multirow{3}{*}{ Yağ Oranı (\%) } & Dinçer & 38.417 & 40.893 & 37.963 & 37.180 & 38.613 \\
\hline & Balcl & 42.273 & 44.113 & 44.077 & 43.037 & 43.375 \\
\hline & $\begin{array}{l}\text { Ortalamalar } \\
\mathrm{LSD}_{0,05} \text { : }\end{array}$ & 40.345 & 42.503 & 41.020 & 40.108 & \\
\hline \multirow{4}{*}{$\begin{array}{l}\text { Ham Protein } \\
\text { Oranı (\%) }\end{array}$} & Dinçer & $13.697 \mathrm{~cd}$ & $12.933 \mathrm{~d}$ & $16.153 \mathrm{ab}$ & $15.587 \mathrm{~b}$ & 14.593 \\
\hline & Balcl & $13.860 \mathrm{~cd}$ & $17.147 \mathrm{a}$ & $16.083 \mathrm{ab}$ & $14.117 \mathrm{c}$ & 15.302 \\
\hline & Ortalamalar & $13.778 \mathrm{c}$ & $15.040 \mathrm{~b}$ & $16.118 \mathrm{a}$ & $14.852 \mathrm{~b}$ & \\
\hline & $\mathrm{LSD}_{0,05}$ & Doz: 0,832 & Çeşit x Doz: 1,177 & & & \\
\hline
\end{tabular}

Aynı harfle gösterilen ortalamalar arasındaki farklılığın "LSD” testine göre (\%5 - \%1) istatistiki açıdan önemli olmadığını göstermektedir.

Çizelge 3. Salisilik asit uygulamasının aspirin verim ve kalite özelliklerine etkisi (2015)

\begin{tabular}{|c|c|c|c|c|c|c|}
\hline \multirow{2}{*}{ Karakterler } & \multirow{2}{*}{ Çeşitler } & \multicolumn{4}{|c|}{ Dozlar } & \multirow{2}{*}{ Ortalamalar } \\
\hline & & $0 \mathrm{mM}$ & $0.1 \mathrm{mM}$ & $0.5 \mathrm{mM}$ & $1 \mathrm{mM}$ & \\
\hline \multirow{4}{*}{$\begin{array}{l}\text { Tabladaki Tohum } \\
\text { Sayısı (adet) }\end{array}$} & Dinçer & 28.167 & 30.700 & 32.900 & 34.333 & $31.525 \mathrm{a}$ \\
\hline & Balcl & 27.733 & 23.367 & 26.200 & 16.833 & $23.533 \mathrm{~b}$ \\
\hline & Ortalamalar & 27.950 & 27.033 & 29.550 & 25.583 & \\
\hline & $\mathrm{LSD}_{0,05}$ & Çeşit: 3,229 & & & & \\
\hline \multirow{4}{*}{ Tabla Çapı (cm) } & Dinçer & 2.383 & 2.470 & 2.427 & 2.583 & $2.466 \mathrm{a}$ \\
\hline & Balcı & 2.163 & 2.190 & 2.283 & 2.047 & $2.171 \mathrm{~b}$ \\
\hline & Ortalamalar & 2.273 & 2.330 & 2.355 & 2.315 & \\
\hline & $\mathrm{LSD}_{0,05}$ & Çeșit: 0,049 & & & & \\
\hline \multirow{4}{*}{$\begin{array}{l}1000 \text { tane ağırlığ } \\
\text { (g) }\end{array}$} & Dinçer & 51.710 & 52.310 & 53.127 & 54.950 & $53.024 \mathrm{a}$ \\
\hline & Balcl & 45.603 & 46.117 & 47.683 & 46.437 & $46.460 \mathrm{~b}$ \\
\hline & Ortalamalar & 48.657 & 49.213 & 50.405 & 50.693 & \\
\hline & $\mathrm{LSD}_{0,05}$ & Çeșit: 2,272 & & & & \\
\hline \multirow{4}{*}{ Kabuk Oranı (\%) } & Dinçer & 48.403 & 46.270 & 48.460 & 49.820 & $48.238 \mathrm{a}$ \\
\hline & Balcl & 40.040 & 39.573 & 38.893 & 39.943 & $39.613 \mathrm{~b}$ \\
\hline & Ortalamalar & 44.222 & 42.922 & 43.677 & 44.882 & \\
\hline & $\mathrm{LSD}_{0,05:}$ & Çeșit: 0,531 & & & & \\
\hline \multirow{4}{*}{$\begin{array}{l}\text { Tohum Verimi } \\
\text { (kg/da) }\end{array}$} & Dinçer & $129.88 \mathrm{a}$ & $124.76 \mathrm{ab}$ & $129.32 \mathrm{a}$ & $107.61 \mathrm{bc}$ & 122.89 \\
\hline & Balcı & $115.84 \mathrm{abc}$ & $96.63 \mathrm{c}$ & $100.71 \mathrm{c}$ & $122.41 \mathrm{ab}$ & 108.90 \\
\hline & Ortalamalar & 122.86 & 110.69 & 115.01 & 115.01 & \\
\hline & $\mathrm{LSD}_{0,05}$ & Çeşit: 21,595 & & & & \\
\hline \multirow{3}{*}{ Yağ Oranı (\%) } & Dinçer & 37.000 & 37.267 & 35.137 & 34.593 & 35.999 \\
\hline & Balcl & 31.397 & 33.637 & 34.113 & 34.757 & 33.476 \\
\hline & $\begin{array}{l}\text { Ortalamalar } \\
\text { LSD }_{0,05} \text { : }\end{array}$ & 34.198 & 35.452 & 34.625 & 34.675 & \\
\hline \multirow{4}{*}{$\begin{array}{l}\text { Ham Protein } \\
\text { Oranı (\%) }\end{array}$} & Dinçer & $13.290 \mathrm{e}$ & $12.827 \mathrm{e}$ & $16.313 \mathrm{ab}$ & $16.610 \mathrm{ab}$ & $14.760 \mathrm{~b}$ \\
\hline & Balcl & $13.430 \mathrm{de}$ & $16.983 \mathrm{a}$ & $15.427 \mathrm{bc}$ & $14.583 \mathrm{~cd}$ & $15.106 \mathrm{a}$ \\
\hline & Ortalamalar & $13.360 \mathrm{c}$ & $14.905 b$ & $15.870 \mathrm{a}$ & $15.597 \mathrm{ab}$ & \\
\hline & $\mathrm{LSD}_{0,05:}$ & Çeșit: 0,110 & Doz: 0,852 & Çeșit x Doz: 1,205 & & \\
\hline
\end{tabular}

Aynı harfle gösterilen ortalamalar arasındaki farklılığın “LSD” testine göre (\%5 - \%1) istatistiki açıdan önemli olmadığını göstermektedir. 


\section{Kabuk oranı (\%)}

Kabuk oranı bakımından çeşitler arasındaki fark her iki yılda da önemli bulunmuştur $(\mathrm{P}<0.05)$. En düşük kabuk oranı her iki yılda da Balcı çeşidinden elde edilmiştir (sırasiyla \%39.698 ve 39.613). SA uygulamasının etkisi ise her iki yılda da istatistiki açıdan önemsiz bulunmuştur $(\mathrm{P}>0.05)$.

\section{Tohum verimi $(\mathrm{kg} / \mathrm{da})$}

Tohum verimi bakımından her iki yılda da çeşit $\mathrm{x}$ doz interaksiyonu önemli bulunmuştur $(\mathrm{P}<0.01) .2014$ ve 2015 yıllarında en yüksek tohum verimi SA uygulanmayan Dinçer çeşidinden elde edilmiştir (sırasıyla 145.36 ve $129.88 \mathrm{~kg} / \mathrm{da}$ ). Tohum verimi, bir çeşit özelliği olması yanında ekolojik faktörlerden ve kültürel uygulamalardan önemli ölçüde etkilenebilmektedir (Tunçtürk, 1998). Araştırmamızda SA dozlarının tohum verimi üzerine olumlu etkide bulunmadı$\breve{g}_{1}$, tohum verimi farklılıklarının çeșit özelliklerinden kaynaklandığı sonucuna varılmıştır.

\section{Yağ oranı (\%)}

Yağ oranı bakımından çeşit $\mathrm{x}$ doz interaksiyonu ve çeșitler arasındaki fark her iki yılda da istatistiki açıdan önemsiz bulunmuştur ( $\mathrm{P}>0.05)$. En yüksek yağ oranı ise 2014 yılında Balcı çeşidinden (\%43.37), 2015 yllında ise Dinçer çeşidinden (\%35.99) elde edilmiştir. Aspir bitkisine çiçeklenme döneminde uygulanan $10^{-5} \mathrm{M}$ salisilik asidin yağ oranı üzerine etkisinin olmadığı bildirilmiştir (Faizan ve Bano, 2011). Ayrica Ahmed ve ark. (2013) salisilik asit uygulamasının ayçiçeğinin yağ oranı üzerine önemli bir etkisinin olmadığını bildirmişlerdir. Bu sonuçlar araştırmamızla paralellik göstermektedir.

\section{Ham protein oranı (\%)}

Düşük dozda SA uygulaması protein oranını olumlu yönde etkilemiştir. SA uygulamasının çeşit $\mathrm{x}$ doz interaksiyonuna etkisi önemli bulunmuş $(\mathrm{P}<0.05)$ ve her iki yılda da en yüksek protein oranı $0.1 \mathrm{mM} \mathrm{SA}$ uygulamasıyla Balcı çeşidinden elde edilmiștir (sıraslyla \%17.15 ve \%16.98). Mona ve ark. (2012) artan salisilik asit dozlarının ayçiçeği tohumlarında protein oranını önemli bir şekilde artırdığını bildirmişlerdir. Protein oranı, tohumlarda yağ alma işleminden sonra geriye kalan küspenin hayvan yemi olarak kullanılabilmesi ve kalitesinin belirlenebilmesi açısından önem arz etmektedir. Bir kısım araştırıcı da salisilik asit uygulamalarının bitkilerde protein ve klorofil içeriğini artırdığını bildirmişlerdir (Tohma, 2007; Özeker, 2015).

\section{Sonuç}

Tekirdağ ekolojik koşullarında 2014 ve 2015 yetişme periyodunda salisilik asit uygulamasının aspir bitkisinde tohum verimi ve bazı kalite özelliklerini belirlemek amacıyla yapılan bu çalışmadan elde edilen sonuçlar bir bütün olarak irdelendiğinde, uygulanan salisilik asit dozlarının tane verimine ve verim öğeleri üzerine olumlu bir etkide bulunmadığı, fakat protein oranı üzerine olumlu etkide bulunduğu sonucuna varılmıştır. Özellikle düşük dozda $(0.1$ $\mathrm{mM}$ ) salisilik asit uygulaması tohumun protein oranını önemli derecede artırmıștır. Protein oranının tohumlarda yağ alma işleminden sonra geriye kalan küspenin hayvan yemi olarak değerlendirilmesinde önem arz ettiği düşünülürse, salisilik asit uygulaması pratik ve ucuz bir yöntem olabilir. Öte yandan bitkisel üretimde verim ve kalitenin sadece bitki büyüme düzenleyicileri (BBD) gibi agronomik uygulamalarla sınırlığı olmadığı, çevre faktörleri ve yetiştirme tekniklerinin de son derece etkili olduğu unutulmamalıdir.

\section{Kaynaklar}

Anonim, 2017. Türkiye İstatistik Kurumu, https://biruni. tuik.gov.tr/Erişim tarihi: 15.02.2018.

Anonymous, 2016. FAOSTAT, Food and Agriculture Organization of The United Nations Statistics Division, http://www.fao.org/faostat/Erişim tarihi: 15.02.2018.

Açıkgöz, N., Akkaş, E., Moghaddam, A., Özcan, K., 1993. Tarist, Pc'ler İçin Türkçe İstatistik Paketi. Ulusal Ekonometri ve İstatistik Sempozyumu, 11-12 Kasım, İzmir.

Ahmed, F., Baloch, D.M., Hassan, M.J., Ahmed, N., 2013. Role of Plant Growth Regulators in Improving Oil Quantity and Quality of Sunflower Hybrids in Drought Stress. Biologia, 59 (2): 315-322.

Arslan, B., Altuner, F., Tunçtürk, M., 2003. Van'da Yetiştirilen Bazı Aspir (Carthamus tinctorius L.) Çeşitlerinin Verim ve Verim Özellikleri Üzerinde Bir Araştırma. Türkiye 5. Tarla Bitkileri Kongresi, 13-17 Ekim, Diyarbakır, s: 468-472.

Arslan, B., Ateş, E., Coşkuntuna, L., 2012. Forage Yield and Some Quality Properties of Safflower (Carthamus tinctorius L.)-Fodder Pea (Pisum arvense L.) Mixtures, as Affected by Sowing Rates in Tekirdag, Romanian Agricultural Research, 29: 255-260.

Baydar, H., Yüce, S., 1996. Aspir (Carthamus tinctorius L.)'de Çiçeklenme İntervalleri, Tabla Çiçeklenme Tarihi ve Tabla Pozisyon Etkisi ile Fitohormonların 
$\mathrm{Bu}$ Özellikler Üzerine Etkileri. Turkish Journal of Agriculture and Forestry, 20 (3): 259-266.

Bayraktar, N., 1991. Seçilmiş Bazı Aspir (Carthamus tinctorius L.) Döllerinde Tohum verimi, Yan Dal Sayısı ve Tabla Sayısının Belirlenmesi. Ankara Üniversitesi Ziraat Fakültesi Yayınları, Ankara, 17 s.

Buban, T., 2000. The Use of Benzyladenine in Orchard Fruit Growing: A Mini Review. Plant Growth Regulation, 32: 381-390.

Budak, N., Çalışkan, C.F., Çaylak, Ö., 1994. Bitki Büyüme Regülatörleri ve Tarımsal Üretimde Kullanımı, Ege Üniversitesi Ziraat Fakültesi Dergisi, 31: 289-296.

Çamaş, N., Ayan, A.K., Çırak, C., 2005. Relationships between seed yield and some characters of safflower (Carthamus tinctorius) cultivars grown in the Middle Black Sea Conditions. VI. International Safflower Conference, İstanbul, 193-198.

Dajue, L., Mündel, H.H., 1996. Safflower, Promoting the Conservation and Use of Underutilized and Neglected Crops. 7. Institute of Plant Genetics and Crop Plant Research, Gatersleben/International Plant Genetic Resources Institute, Rome, Italy.

Ebrahimzadeh, L., Farahbakhsh, H., Arvin, S.M.J., 2009. Response of Safflower (Carthamus tinctorius L.) Growth and Development to Exogenous Application of Plant Growth Regulators. Plant Ecophysiology, 2: 57-61.

Esendal, E., 1981. Aspir'de Değişik Sıra Aralıkları ile Farklı Seviyelerde Azot ve Fosfor Uygulamalarının Verim ve Verimle İlgili Bazı Özellikler Üzerine Etkileri (Doçentlik tezi, basılmamış). Atatürk Üniversitesi, Ziraat Fakültesi, Erzurum.

Faizan, U., Bano, A., 2011. Effect of Plant Growth Regulators on Oil Yield and Biodiesel Production of Safflower (Carthamus tinctorius L.). Brazilian Journal of Plant Physiology, 23 (1): 27-31.

İşler, N., 2010. Aspir Tarımı (Basılmamış ders notları). Mustafa Kemal Üniversitesi, Ziraat Fakültesi, Tarla Bitkileri Bölümü, Hatay, 86 s.

Khaliliaqdam, N., Mahmoodi, T., Soleiman Zadeh, H., 2013. Effect of Salicylic Acid Seed Priming on Barley Yield. Academia Journal of Biotechnology, 1 (7): 109113.

Kleier, D.A., 1988. Phloem Mobility of Xenobiotics. I. Mathematical Model Unifying the Weak Acid and Intermediate Permeability Theories. Plant Physiology, 86: 803-810.

Modhej, A., Naderi, A., Emam, Y., Aynehband, A., 2008. Effects of Post-Anthesis Heat Stress and Nitrogen
Levels on Grain Yield in Wheat (T. durum and T. aestivum) Genotypes. International Journal of Plant Production, 2 (3): 257-267.

Moghadam A.K., Mohammadi, K., 2014. A Laboratory and Glasshouse Evaluation of Ascorbic and Salicylic Acid Effect on Germination Traits and Grain Yield of Safflower Cultivars. Environmental and Experimental Biology, 12: 39-42.

Mona, G.D., Mervat, S., Hozayen, M., 2012. Physiological Role of Salicylic Acid in Improving Performance, Yield and Some Biochemical Aspects of Sunflower Plant Grown under Newly Reclaimed Sandy Soil. Australian Journal of Basic and Applied Sciences, 6 (4): 82-89.

MSTAT, 1989. Mstat-C, A Microcomputer Program for the Design, Management and Analysis of Agronomic Research Experiments. Michigan State University.

Özeker, E., 2005. Salisilik Asit ve Bitkiler Üzerindeki Etkileri. Ege Üniversitesi Ziraat Fakültesi Dergisi, 42 (1): 213-223.

Öztürk, Ö., 1994. Konya Ekolojik Şartlarında Bazı Aspir (Carthamus tinctorius L.) Çeşitlerinde Verim ve Verim Unsurlarının Tespiti. Selçuk Üniversitesi Fen Bilimleri Enstitüsü. Yüksek Lisans Tezi, Konya, 69 s.

Palavan-Ünsal, N., 1993. Hormonlar ve Meyvelenme. Bitki büyüme maddeleri. İstanbul Üniversitesi Basım Evi Film Merkezi. Üniversite Yayın No:3677, 197-211.

Shakirova, F.M., Sakhabutdinova, A.R., Bezrukova, M.V., Fatkhutdinova, R.A., Fatkhutdinova, D.R., 2003. Changes in the Hormonal Status of Wheat Seedlings Induced by Salicylic Acid and Salinity. Plant Science, 164: 317-322.

Tunçtürk, M., 1998. Van Ekolojik Koşullarında Azotlu Gübre Form ve Dozlarının Aspir (Carthamus tinctorius L.)'de Verim ve Verim Unsurları Üzerine Etkileri. Yüzüncü Yıl Üniversitesi, Fen Bilimleri Enstitüsü. Yüksek Lisans Tezi, Van, 62 s.

Tohma, Ö., 2007. Çilekte Salisilik Uygulamasının Tuz Stresine Dayanıklılık Üzerine Etkisi. Atatürk Üniversitesi, Fen Bilimleri Enstitüsü, Yüksek Lisans Tezi, Erzurum, $61 \mathrm{~s}$

Uysal, N., Baydar, H., Erbaş, S., 2006. Isparta Populasyonunda Geliştirilen Aspir (Carthamus tinctorius L.) Hatlarının Tarımsal ve Teknolojik Özelliklerinin Belirlenmesi. Süleyman Demirel Üniversitesi, Ziraat Fakültesi Dergisi, 1 (19): 52-63.

Weiss, E. A., 2000. Safflower. In: Oilseed Crops, Blackwell Sci. Ltd., Victoria, Australia. 